\title{
NOTES ON SOME NEW MEXICO BUTTERFLIES.
}

BY T. D. A. COCKIRELL, N. M. AGR. EXP. STA.

Lemonias Duryi, Edwards.-I have before me a $q$ taken by $\mathrm{Mr}$. S. Macgregor in 1898 between Mesilla Park and the Organ Mts. N. M.; that is, in the exact type locality of the species, originally collected by Mr. Dury in 1881. The specimen expands an inch and a half, and is thus larger than Dury's, but is otherwise the same. I do not know why Dr. Holland states (Butterfly Book, p. 290) that the $q$ L. Duryi figured by him is the only one known: Dury took several and Edwards described from both sexes.

Anosia strigosa, Bates.-A beautiful specimen of this insect was taken (1898) by Mr. S. Macgregor close to Litule Mountain, Mesilla Valley, N. M.

Heterockroa (or Adelpha) califomica, Butler_-This beautiful butterfly is Common in the Organ Mts., N. M., a mose eastern locality than any I I find recorded for it.

Salyrus Meadi, Edw.,-Fillmore Canon, Organ Mts., N. M., Aug. 29; collected by Prof. C. H. T. Townsend.

Neonympha Henshawi, Edw.-This is rather common at Dripping Springs, Organ Mis. N. M., $5600 \mathrm{ft}$, and I took it on Tuerto Mtn, near Santa Fć, Aug. 7, at $8875 \mathrm{ft}$. Thus it has a vertical range of at least $3275 \mathrm{ft}$.

Melitaeachara, Edw-Common flying in a grassy spot near the western base of the Organ Mts., N. M., 1898. (Ckll. and S. Macgregor). This is an austral representative of the subalpine or subboreal $M$. minuta, the latter flying at much higher altitudes. $M$. chara has hitherto been rcported only from Arizona.

Chlorippe montis, Edw.-Common on the western side of the Organ Mts. Y. M., at about $5000 \mathrm{ft}$, in the neighbourhood of Celtis bushes. This is the Upper Sonoran represcntative of the Lower Sonoran C. antonia. The Organ Mt. examples are strongly fulvous above, not pale ashen-gray as Holland (Butterfly Brok, p. 190) has it. Edwards (Papilio, Vol. IU., p 7 ) states that this type of montis were fulvous above. All that I have seen have the ocellus in the lower median interspace blind, while that in the upper has a white spot.

Phyciodes nycteis, Dbl. and Hew.-Taken by Prof. E. O. Wooton, on Ruidoso Creek, N. M. 
Eresia lexana, Edw.-Dripping Spring, Organ Mts., N. M., $5600 \mathrm{ft}$., April 20. (Ck11.)

Calopsilia sennae, L--Mesilla Valley, N. M. Mr. S. Macgregor took a $q$ var. orbis, Poey, near Little Mountain. The varieties named orbis, Poey; pallida, Ckll.; hyperice, Sepp., and pomona, Donov., appear to be practically identical.

Euchloc Reakirti, Ldw.-I took a ${ }^{+}$of this at Dripping Spring, Organ Mts., N. M., April 21. The lower wings are delicately suffused with lemon-rellow, showing some transition towards stella, but in all other respects the insect is true Reakirti. The insect has hitherto, I believe, only been found in California.

Lycatna acmon, Dbl. and Hew.-This species has a vertical range of at least 6000 ft.! At Mesilla Park, N. M., I bred it from Astragalus Wootoni, Shelcion.

Thanaos clitus, Edw.-I saw, but failed to capture, an example of this heautiful specics at the western base of the Organ Mts., N. M., at the end of August. My recoliection of it accords exactly with the figure in Dr. Holland's "Butterfly Book."

The following 14 species were collected by Mr. W. J. Howard in Grant Co., N. M. :

Satyrus alope, race nephele, Kirby.- o. Similar to fig. 4, Pl. XXVI., of Holland's "Butterfly Book," except that there are three of the minute ocelli on the under side of the secondaries. This really belongs to Fiwards's race olympus, by its locality and comparatively pallid colour; but the ocelli on the primaries are much larger than in Edwards's fig. 6 , P1. III., of Satyrus.

Melitaca leanira, race fulvia, Edw.-In the specimen before me, the secondaries beneath are yellowish-white with black markings, instead of "yellow-buff," but they may have faded. 'There is much resemblance to the Californian, M. Wrightii, as figured by Holland, but there is not the fulvous at the base of the primaries, and the seconclaries beneath are not so heavily marked in our insect.

Melitaea thekla, Edw-One specimen. Euranessa antiopa, L.; Pyrameis cardui, L.; P. huntera, Fab.; Euptoieta claudia, Cram.; Synchloe lacinia, var. crocale, Edw.; Anosia archippus, Fab.; Meganostoma caesonia, Stoll.; Colias eurytheme, Boisd.; Terias mexicana, Boisd.; T. nicippe, Cram.; and Heterochroa californica, Butler. 